\title{
Protective Effect of Naringin against Pylorus Ligation- induced Esophagitis in Male Wistar Rats
}

\author{
C. SHALINI, P. KUMAR, K. A. SINGH, R. VINIT, R. AMIT, K. K. AMIT, ${ }^{1}$ A. PRAKASH AND S. SAHA* \\ Department of Pharmaceutical Sciences, ${ }^{1}$ Department of Biotechnology, Babasaheb Bhimrao Ambedkar \\ University, Vidya Vihar, Lucknow-226 025, India
}

\section{Shalini, et al.: Naringin and Pylorus Ligation-induced Esophagitis in Rats}

\begin{abstract}
The present study was undertaken to evaluate the effect of naringin, a naturally occurring flavonoid, on experimental esophagitis in Wistar rats. Animals divided into six groups and received carboxymethyl cellulose $(0.25 \%, 3 \mathrm{ml} / \mathrm{kg}$, sham control), standard pantoprazole $(30 \mathrm{mg} / \mathrm{kg})$ and naringin $(100,200$ and $300 \mathrm{mg} / \mathrm{kg}$ ) for $7 \mathrm{~d}$ orally and subjected to pylorus and forestomach ligation. All animals were sacrificed after $8 \mathrm{~h}$ and evaluated for various physiological parameters like total acidity, free acidity, gastric $\mathrm{pH}$, volume of gastric juices and esophagitis index. Esophagitis regions were further subjected to estimation of various oxidative stress parameters including thiobarbituric acid reactive substances, glutathione, catalase and superoxide dismutase. Later, histopathology and scanning electron microscopy of esophagitis regions were also performed to evaluate protective action of naringin. Results revealed that treatment with pantoprazole and naringin significantly inhibited the gastric secretion, total acidity and esophagitis index. Various oxidative stress parameters were restored to normal level in the treatment groups. Histopathology and scanning electron microscopy analyses demonstrated the protective action of naringin as evidenced by normal tissue architecture of esophagitis regions. These findings indicate the potential of naringin against esophagitis.
\end{abstract}

Key words: Naringin, esophagitis, oxidative stress, histopathology, scanning electron microscopy

Gatroesophageal reflux disease (GERD) is defined as the reflux of stomach content back to esophagus, which resulted in mucosal damage and oxidative stress. Ten to twenty percent people of Western countries and India are affected with this disease ${ }^{[1]}$. Recent investigation suggested that GERD condition leads to damage the mucosal and sub mucosal cells, which release various antiinflammatory mediators ${ }^{[2]}$. This biochemical process finally enumerates for various pathophysiological conditions like irritable bowel syndrome and functional dyspepsia ${ }^{[3]}$. Proton pump inhibitors and $\mathrm{H}_{2}$ receptor blockers are mainly used to treat GERD, however their clinical effectiveness is poor because of weak inhibitory activity and low activity at initial hour of dosing ${ }^{[4]}$. On the contrary, compounds obtained from natural origin appear to be safe, less toxic as compared to synthetic agents ${ }^{[5]}$. Various flavonoids have been shown to protect gastric mucosa through a prostaglandin-like action ${ }^{[6]}$.

Naringin, $\quad$ 4',5,7-trihydroxyflavanone-7rhamnoglucoside (fig. 1), obtained from various species of citrus, was reported to be effective in inflammation,

*Address for correspondence E-mail: sudiptapharm@gmail.com

March-April 2017 atherosclerosis, diabetes and neurogenrative disorders ${ }^{[7]}$. Naringin and other flavonoids scavenged free radicals due to the presence of phenolic hydroxyl groups $^{[8-11]}$. Naringin also had antiulcer effect against ethanol-induced gastric lesion in rats ${ }^{[12]}$. Based on the above information, it would be of interest to evaluate if naringin had any effect against esophagitis. A study was designed in which standard pantoprazole (30 $\mathrm{mg} / \mathrm{kg})$ and naringin $(100,200$ and $300 \mathrm{mg} / \mathrm{kg}$ ) were given orally for $7 \mathrm{~d}$ to rats subjected to pylorus and forestomach ligation. Total acidity, free acidity, gastric $\mathrm{pH}$ and volume of gastric juices were evaluated in treated and control animals. Esophagitis regions were explored for levels of thiobarbituric acid reactive substances (TBARS), glutathione (GSH), catalase (CAT) and superoxide dismutase (SOD). Inflammatory

This is an open access article distributed under the terms of the Creative Commons Attribution-NonCommercial-ShareAlike 3.0 License, which allows others to remix, tweak, and build upon the work non-commercially, as long as the author is credited and the new creations are licensed under the identical terms

Accepted 10 March 2017

Revised 17 December 2016

Received 07 September 2016

Indian J Pharm Sci 2017;79(2):250-256 


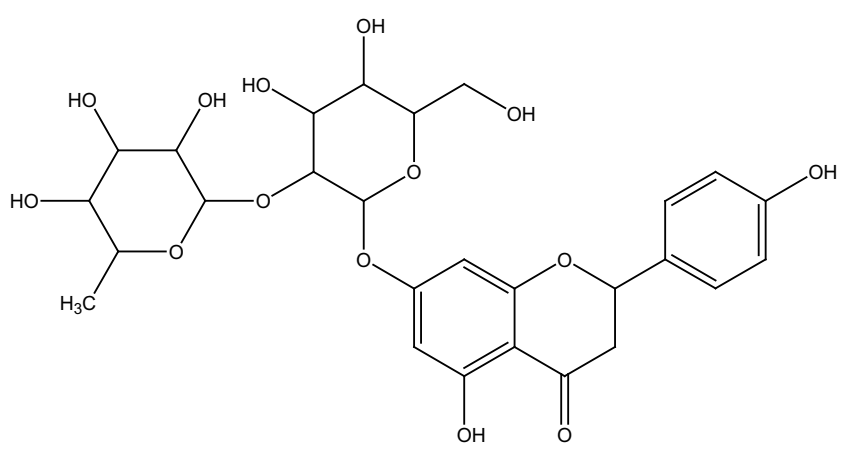

Fig. 1: Chemical structure of naringin

lesions were further subjected to histopathology and scanning electron microscopy (SEM) to get a measure of the protective action of naringin.

\section{MATERIALS AND METHODS}

Pyrogallol and guanidine hydrochloride were purchased from Loba Chemicals, New Delhi, India. GSH and thiobarbituric acid were procured from S. D. Fine Chem, Mumbai, India. 2,4-dinitrophenylhydrazine was procured from Sigma Aldrich, Bengaluru, India. All other chemicals were obtained from HiMedia, Mumbai, India. All the solvents and chemicals were of analytical grades with $99 \%$ purity and in house distilled water was used throughout the experiment.

\section{Experimental animals:}

Male Wistar rats (110-130 g) were used for this experiment and the protocol was approved by the Institutional Animal Ethics Committee (IAEC) (Approval No. UIP/IAEC/2014/FEB/05/R1). Rats were housed in polypropylene cages (4 animals per cage) with standard conditions (temperature $\left(25 \pm 5^{\circ}\right)$ and relative humidity $(55 \pm 10 \%))$. They were acclimatized for $7 \mathrm{~d}$ with $12 \mathrm{~h}$ light-dark cycle. Rats were fed a standard pellet diet and had free access to water during acclimatization.

\section{Experimental design:}

Rats were divided into six groups randomly with six animals in each group. Group I served as normal control (NC) and received $0.25 \%$ carboxymethyl cellulose (CMC), $3.0 \mathrm{ml} / \mathrm{kg}$ orally, group II was designated esophagitis control, which too received $0.25 \%$ CMC, $3.0 \mathrm{ml} / \mathrm{kg}$ orally, group III animals received pantoprazole $30 \mathrm{mg} / \mathrm{kg}$ orally, group IV animals received naringin $100 \mathrm{mg} / \mathrm{kg}$ orally, group $\mathrm{V}$ animals received naringin $200 \mathrm{mg} / \mathrm{kg}$ orally, group VI animals received naringin $300 \mathrm{mg} / \mathrm{kg}$ orally. After seven days, group II to VI rats were ligated carefully between the fore stomach and corpus with 2-0 silk thread and group I served as vehicle control. All the treatments were given orally for seven days. Most recent literature related to the therapeutic response of natural product reported $100 \mathrm{mg} / \mathrm{kg}$ dose for seven days ${ }^{[13]}$. On that basis, in the current investigation a similar dose and higher doses were chosen to understand dosedependency of the response. Animals were fasted overnight prior to surgical procedure. Next day, animals were anaesthetized using thiopentone sodium $(50 \mathrm{mg} / \mathrm{kg}$, intraperitoneally) and then coeliotomy was performed. The abdomen of each animal was opened by a midline incision of about $2 \mathrm{~cm}$ and rats were ligated carefully between the fore stomach and corpus with a 2-0 silk thread. The incised regions were immediately sutured before being returned to their home cages ${ }^{[14]}$. The animals were sacrificed by cervical dislocation after six hour and stomach was opened along the greater curvature and esophagus was removed. The $\mathrm{pH}$ of the gastric juice was measured using a $\mathrm{pH}$ meter. Physiological parameters like total acidity, free acidity and volume of gastric juice were also measured during the experiment. Later, esophagus was kept at $-20^{\circ}$ and various oxidative stress parameters were measured.

\section{Volume of gastric content and $\mathrm{pH}$ of gastric content:}

After amputation of the stomach, gastric content was emptied in a centrifuge tube and centrifuged at 1000 rpm for $10 \mathrm{~min}$. The volume of supernatant was estimated and expressed in $\mathrm{ml} / 100 \mathrm{~g}$ of body weight. One millilitre of gastric juice was transferred to a glass tube and $\mathrm{pH}$ was directly measured ${ }^{[15]}$.

\section{Free acidity and total acidity of gastric content:}

One milliliter of the supernatant was pipetted out in a conical flask and diluted to $10 \mathrm{ml}$ with distilled water. The solution was titrated against $0.1 \mathrm{~N}$ sodium hydroxide using 2-3 drops of Topfer's reagent as an indicator till all traces of red colour disappeared and yellowish orange colour remained. The amount of alkali consumed was expressed as corresponding to the free acid present in the gastric content. The titration was continued by adding 2-3 drops of phenolphthalein reagent up to the endpoint till the red colour reappeared. The volume of sodium hydroxide was equal to the amount required to neutralize the combined acid present in the gastric content. Thus the total amount of the titrant was total acidity of the gastric content ${ }^{[16]}$. Acidity was estimated by following Eqn., acidity = volume of $\mathrm{NaOH} \times$ normality of $\mathrm{NaOH} /$ volume of gastric juice consumed. 
Determination of oxidative stress parameters:

About $10 \% \mathrm{w} / \mathrm{v}$ of tissue homogenate was prepared using distilled water and was further subjected to screen for TBARS, SOD, CAT and GSH estimations. By colorimetric protein assay, total protein of each sample was estimated using Bradford reagent and all the biochemical results were normalized using bovine serum albumin as standard protein.

\section{TBARS:}

In order to evaluate oxidative damage or lipid peroxidation, formation of TBARS was measured during acid-heating reaction. The reaction mixture containing $1 \mathrm{ml}$ aliquots of homogenates, $0.5 \mathrm{ml}$ of $30 \%$ trichloroacetic acid (TCA) and $0.5 \mathrm{ml}$ of $0.8 \%$ TBA was kept in a water bath at $80^{\circ}$ for $30 \mathrm{~min}$ followed by ice-cold water for $15 \mathrm{~min}$. After centrifuging at $3000 \mathrm{rpm}$ for $15 \mathrm{~min}$, the absorbance of the upper layer was recorded at $535 \mathrm{~nm}$ against a blank $(1 \mathrm{ml}$ distilled water, $0.5 \mathrm{ml}$ TCA and $0.5 \mathrm{ml} \mathrm{TBA})^{[16]}$. The amount of TBARS was estimated using the Eqn., nM of malondialdehyde $(\mathrm{MDA}) / \mathrm{mg}$ of protein $=(\mathrm{V} \times \mathrm{OD}$ at $540 \mathrm{~nm}) /(0.56 \times$ protein concentration $)$, where, $\mathrm{V}$ is final volume of the test solution and OD is the optical density of the samples.

\section{SOD:}

SOD, a free radical scavenging enzyme is estimated by the ability to inhibit pyrogallol auto-oxidation. About $100 \mu \mathrm{l}$ of the cytosol supernatant was added to TRIS buffer ( $\mathrm{pH} 8.5$ ) and volume was adjusted to 3 $\mathrm{ml}$. Then $25 \mu \mathrm{l}$ of pyrogallol was added and change in absorbance was measured against a blank at $420 \mathrm{~nm}$ at 1 min interval 3 times. One unit of SOD activity is defined as the activity that doubles the autoxidation rate of the control blank $(\mathrm{Vs} / \mathrm{Vc}=2)^{[16]}$. The unit of SOD was expressed as units/mg protein and described by Eqn., unit of SOD $/ \mathrm{mg}$ of protein $=100 \times(\mathrm{A}-\mathrm{B}) /(\mathrm{A} \times 50)$.

\section{CAT:}

CAT converts two molecules of $\mathrm{H}_{2} \mathrm{O}_{2}$ to 1 molecule of oxygen and two molecules of water. The activity of tissue CAT was assessed in homogenates $(10 \% \mathrm{w} / \mathrm{v})$ mixed with $50 \mathrm{mM}$ potassium phosphate buffer. The resulting suspension was centrifuged at $10000 \mathrm{rpm}$ for $20 \mathrm{~min}$ and the supernatant was employed for enzymatic assay. Following first order kinetics, decrease in $\mathrm{H}_{2} \mathrm{O}_{2}$ (19 $\mathrm{mM}$ ) concentration in $50 \mathrm{mM}$ potassium phosphate buffer was measured spectrophotometrically against a blank at $240 \mathrm{~nm}$ at $1 \mathrm{~min}$ interval for 3 times $^{[16]}$.
The tissue CAT activity was calculated as an Eqn., $\mathrm{nM} / \mathrm{min} / \mathrm{mg}$ of protein $=(\Delta \mathrm{A} / \mathrm{min} \times$ volume of assay $) /$ $(0.0719 \times$ volume of sample $\times \mathrm{mg}$ of protein $)$

\section{GSH:}

GSH is produced on reduction of GSH disulphide and oxidation of NADPH by GSH reductase. About 0.2 $\mathrm{ml}$ of the tissue homogenate and $1.8 \mathrm{ml}$ of distilled water were coalesced in a test tube. Promptly, $3 \mathrm{ml}$ of precipitating solution $(1.67 \mathrm{~g}$ of glacial metaphosphoric acid, $0.20 \mathrm{~g}$ of disodium ethylene diamine tetra acetate and $30 \mathrm{~g}$ of sodium chloride dissolved in $100 \mathrm{ml}$ distilled water) was added and filtered it after $5 \mathrm{~min}$ through coarse grade filter paper. $0.2 \mathrm{ml}$ of the protein free supernatant and $1 \mathrm{ml}$ of $0.4 \%(\mathrm{w} / \mathrm{v})$ 5,5'-dithio-bis-2-nitrobenzoicacid (DTNB) were comingled with $8.0 \mathrm{ml}$ of $0.3 \mathrm{M}$ phosphate solution and centrifuged (at $13000 \mathrm{rpm}$ ) for $1 \mathrm{~min}^{[16]}$. GSH (mM/mg of protein $)=(310.4 \times \mathrm{Ei} \mathrm{OD}$ at $412 \mathrm{~nm}) /(\mathrm{mg}$ of protein $)$, where, Ei is the correction factor (0.542).

\section{SEM:}

Esophagitis samples were mixed with $2.5 \%$ glutaraldehyde and kept at $4^{\circ}$ for 2 to $6 \mathrm{~h}$. The samples were washed with $0.1 \mathrm{M}$ phosphate buffer three times at $15 \mathrm{~min}$ intervals. Post fixer reagent, $1 \%$ osmium tetroxide was added to it and kept for $2 \mathrm{~h}$ at $4^{\circ}$. Again, the samples were washed in $0.1 \mathrm{M}$ phosphate buffer for 3 times at $15 \mathrm{~min}$ intervals. Continuously, the samples were dehydrated using increasing concentration of dry acetone $30,50,70,90,95$ and 100\% concentrations, to remove water from samples at $4^{\circ}$ for 30 min period. Moreover, specimens were dried in air at critical point drying $\left(31.5^{\circ}\right.$ at $\left.1100 \mathrm{psi}\right)$. Lastly, samples were mounted on to the aluminium stubs with adhesive tape and observed for scanning electron microscope (JSM6490LV. Jeol, Japan) ${ }^{[17]}$.

\section{Histopathological studies:}

Esophagus was fixed in neutral buffered $10 \%$ formalin for $\geq 48 \mathrm{~h}$, bisected and embedded in paraffin wax. Sections of $5 \mu \mathrm{m}$ thickness were cut from fixed tissue in paraffin cubes with the help of microtome (Unimeditrek YSI-060 semiautomatic rotary microtome, India) and subjected to stain with haematoxylin and eosin, and subsequently examined under the microscope with 40X magnification (Nikon eclipse TS 100, UK) ${ }^{[18]}$.

\section{Statistical analysis:}

Statistical analysis was carried out using GraphPad 
Prism 5.0 (San Diago, CA, USA). All results were expressed as mean \pm standard deviation (SD). The data was analysed by one-way ANOVA followed by Bonferroni multiple comparison test. Statistical significance differences were considered with respect to esophagitis control $(\mathrm{P}<0.001)$.

\section{RESULTS AND DISCUSSION}

Necrosis and ulceration were found at the esophagus site, which was most prominent during microscopic observation. Naringin at 100, 200, $300 \mathrm{mg} / \mathrm{kg}$ doses significantly reduced the esophagitis. It restored the gastric volume and total acidity as compared to esophagitis control (Table 1). Naringin decreased the volume of gastric juices, total acidity and increased the gastric $\mathrm{pH}$, suggesting that naringin was active against esophagitis.

During esophagitis, free radicals were generated from inflammation site, which ultimately led to oxidative damage of esophagus cells. Therefore, various oxidative stress related parameters like GSH, TBARS, SOD and CAT were measured in esophagitis tissue to evaluate the mechanism of action of naringin. As depicted in Table 2, GSH level was significantly decreased in esophagitis group $(\sim 2.07 \mu \mathrm{M})$ as compared to normal $(\sim 4.30 \mu \mathrm{M})$. GSH concentration restored to normal after oral administration of naringin at 200 and 300 $\mathrm{mg} / \mathrm{kg}$ doses. In the TBARS assay, it was found that the MDA formation was higher for esophagitis control ( $\sim 0.12 \mathrm{nM}$ ), which was brought to normal during naringin treatment $(\sim 0.06 \mathrm{nM})$.

Liver CAT and SOD enzymes were also measured to determine the mechanism of action of naringin. CAT is most abundant in the liver, which is mainly responsible for the catalytic decomposition of $\mathrm{H}_{2} \mathrm{O}_{2}$ to oxygen and water. $\mathrm{H}_{2} \mathrm{O}_{2}$ concentration was increased in naringin treated rats and this result depicted that there was higher amount of CAT enzyme available in the tissue to decompose $\mathrm{H}_{2} \mathrm{O}_{2}$ with respect to esophagitis control. As shown in Table 2, it was observed that SOD enzyme level also dramatically increased in naringin-treated samples than esophagitis control (Table 2).

Histopathology of rat esophagus revealed that deeply penetrating necrotic tissue inside the muscle was found in esophagitis control (fig. 2). These lesions were less prominent in naringin-treated rats with 200 and $300 \mathrm{mg} / \mathrm{kg}$ dose (fig. 2). SEM analysis supported the previous trends and the presence of lesions were observed in the esophagitis control groups, which was absent in naringin-treated groups (fig. 3).

Recent investigation suggested that natural products such as rutin, harmaline ${ }^{[19]}$ and lycopene ${ }^{[20]}$ were

TABLE 1: EFFECT OF NARINGIN ON ACID SECRETARY PARAMETERS DURING ESOPHAGITIS

\begin{tabular}{|c|c|c|c|c|}
\hline Treatment & $\mathrm{pH}$ & $\begin{array}{c}\text { Volume of } \\
\text { gastric juice } \\
(\mathrm{ml} / 100 \mathrm{~g})\end{array}$ & $\begin{array}{c}\text { Total acidity } \\
(\mathrm{mEq} / \mathrm{l})\end{array}$ & Free acidity (mEq/l) \\
\hline Control (3 ml/kg, 0.25\% CMC) & $3.18 \pm 0.13$ & $0.675 \pm 0.18$ & $88.48 \pm 0.68$ & $43.89 \pm 0.39$ \\
\hline Esophagitis control ( $3 \mathrm{ml} / \mathrm{kg}, 0.25 \% \mathrm{CMC})$ & $1.96 \pm 0.15$ & $2.12 \pm 0.28$ & $160.60 \pm 1.24$ & $82.69 \pm 3.68$ \\
\hline Pantoprazole (30 mg/kg) & $2.46 \pm 0.21^{*}$ & $1.05 \pm 0.13^{*}$ & $92.57 \pm 0.94^{*}$ & $48.63 \pm 4.87^{*}$ \\
\hline Naringin $(100$ mg/kg) & $2.13 \pm 0.16^{*}$ & $1.2 \pm 0.15^{*}$ & $85.59 \pm 1.15^{*}$ & $59.85 \pm 2.72 *$ \\
\hline Naringin $(200$ mg/kg) & $2.63 \pm 0.15^{*}$ & $0.87 \pm 0.06^{*}$ & $73.94 \pm 3.83^{*}$ & $54.53 \pm 2.83^{*}$ \\
\hline Naringin $(300$ mg/kg) & $2.82 \pm 0.12$ & $0.80 \pm 0.03^{*}$ & $72.57 \pm 4.94^{*}$ & $58.63 \pm 3.87^{*}$ \\
\hline
\end{tabular}

Six animals per each group $(n=6)$. All data are presented as mean \pm SD, statistical significant differences were observed between esophagitis control and treated samples using one way-ANOVA followed by Bonferroni multiple comparison test $\left({ }^{*} \mathrm{P}<0.001\right)$

TABLE 2: EFFECT OF NARINGIN ON VARIOUS OXIDATIVE STRESS PARAMETERS DURING ESOPHAGITIS

\begin{tabular}{|c|c|c|c|c|}
\hline Treatment & 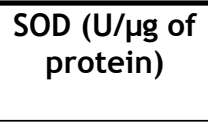 & $\begin{array}{c}\text { CAT (nM of } \\
\mathrm{H}_{2} \mathrm{O}_{2} / \mathrm{min} / \mu \mathrm{g} \text { of } \\
\text { protein) }\end{array}$ & $\begin{array}{c}\text { Reduced GSH } \\
(\mu \mathrm{M} / \mu \mathrm{g} \text { of protein) }\end{array}$ & $\begin{array}{c}\text { TBARS ( } \mathrm{nM} \\
\text { of MDA/ } \mu \mathrm{g} \text { of } \\
\text { protein) }\end{array}$ \\
\hline Control (3 ml/kg, 0.25\% CMC) & $7.06 \pm 0.02$ & $1.82 \pm 0.24$ & $4.30 \pm 0.05$ & $0.06 \pm 0.01$ \\
\hline Esophagitis control ( $3 \mathrm{ml} / \mathrm{kg}, 0.25 \% \mathrm{CMC}$ ) & $2.05 \pm 0.02$ & $0.43 \pm 0.16$ & $2.07 \pm 0.13$ & $0.12 \pm 0.03$ \\
\hline Pantoprazole (30 mg/kg) & $6.07 \pm 0.16^{*}$ & $1.10 \pm 0.37^{*}$ & $4.16 \pm 0.19^{*}$ & $0.05 \pm 0.02 *$ \\
\hline Naringin $(100 \mathrm{mg} / \mathrm{kg})$ & $4.75 \pm 0.22^{*}$ & $1.13 \pm 0.17^{*}$ & $3.60 \pm 0.16^{*}$ & $0.06 \pm 0.01^{*}$ \\
\hline Naringin $(200 \mathrm{mg} / \mathrm{kg})$ & $4.79 \pm 0.15^{*}$ & $1.58 \pm 0.12^{*}$ & $4.20 \pm 0.16^{*}$ & $0.06 \pm 0.01 *$ \\
\hline Naringin $(300 \mathrm{mg} / \mathrm{kg})$ & $4.89 \pm 0.24^{*}$ & $1.60 \pm 0.04^{*}$ & $4.15 \pm 0.15^{*}$ & $0.05 \pm 0.01^{*}$ \\
\hline
\end{tabular}

Six animals per each group $(n=6)$. All data are presented as mean $\pm S D$, statistical significant differences were observed between toxic control and treated samples using one way-ANOVA followed by Bonferroni Multiple Comparison test ( $\left.{ }^{*}<0.001\right)$ 


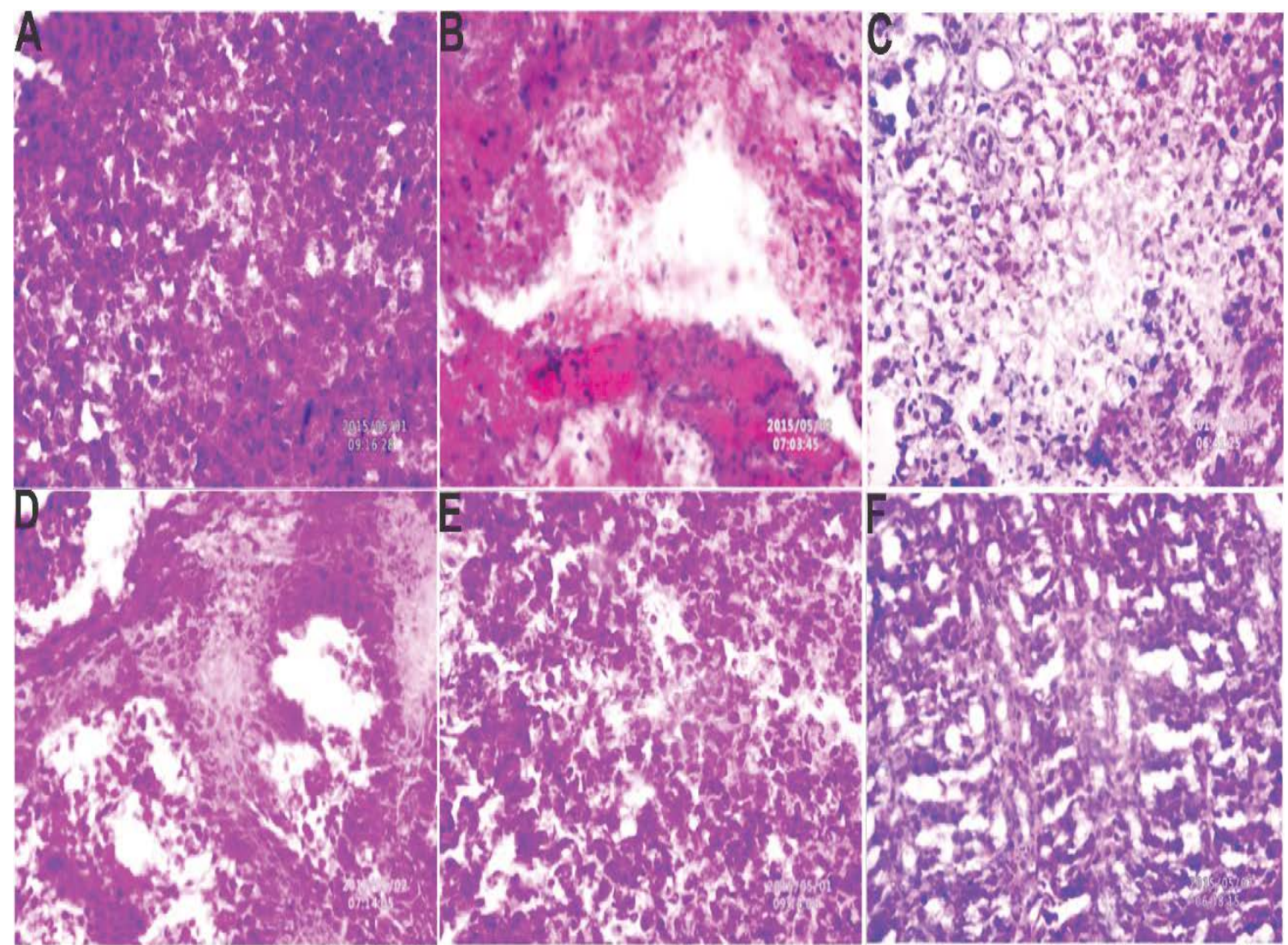

Fig. 2: Histopathology of esophagus

(A) Control, (B) esophagitis control (C) pantoprazole (30 mg/kg), (D) naringin (100 mg/kg), (E) naringin (200 mg/kg) and (F) naringin $(300 \mathrm{mg} / \mathrm{kg})$

active against esophagitis because of their capacity to neutralize free radicals generated from esophagitis regions. In this study, esophagitis cells showed remarkable toxicity during pylorus ligation. Naringin reduced the toxicity in a dose-dependent manner and esophagitis cells restored to normal during treatment. Naringin raised the gastric $\mathrm{pH}$ and reduced total acidity, gastric juice secretion as compared to esophagitis control.

Although naringin reduced the secretion of acid and increased the $\mathrm{pH}$ of gastric juice, it was necessary to investigate the mechanism of action of this compound against esophagitis. Hence, various biochemical investigations were performed to evaluate its mechanism of action. Tissue GSH levels were measured and it was found that GSH level restored to normal after naringin administration at $300 \mathrm{mg} / \mathrm{kg}$ dose. GSH plays a major role in the oxidation-reduction process, resulting in the formation of disulphide glutathione (GSSG) during oxidative damage ${ }^{[19]}$. It was observed that naringin had protective action on GSH and reduced its oxidation during administration. Again, MDA has been reported to increase during reflux esophagitis, which is the indicator of oxidative stress damage $^{[21]}$. Formation of MDA in esophagitis control rats represented that esophagitis tissue membranes were oxidized during esophagitis. This formation was reduced during naringin administration. This was an indirect indication that naringin reduce the release of free radicals, however, it was necessary to perform other oxidative stress parameters to check the mechanism of action of naringin.

For further assessment of protective action against oxidative stress-induced damage, both CAT and SOD enzyme levels were measured in the infected tissue. The enzyme CAT is also most abundant in liver, which catalyses the conversion of $\mathrm{H}_{2} \mathrm{O}_{2}$ to corresponding oxygen and water. This enzyme action is reduced due to the presence of peroxides and reactive oxygen species ${ }^{[22]}$. Increase in concentration of $\mathrm{H}_{2} \mathrm{O}_{2}$ in naringintreated groups depicted that there was higher amount of CAT enzyme available in the tissue to decompose the $\mathrm{H}_{2} \mathrm{O}_{2}$ with respect to esophagitis control. This assay indirectly indicated that oral administration of naringin increased the level of CAT enzyme in the inflamed esophagus. Separately, the estimation of SOD levels in 

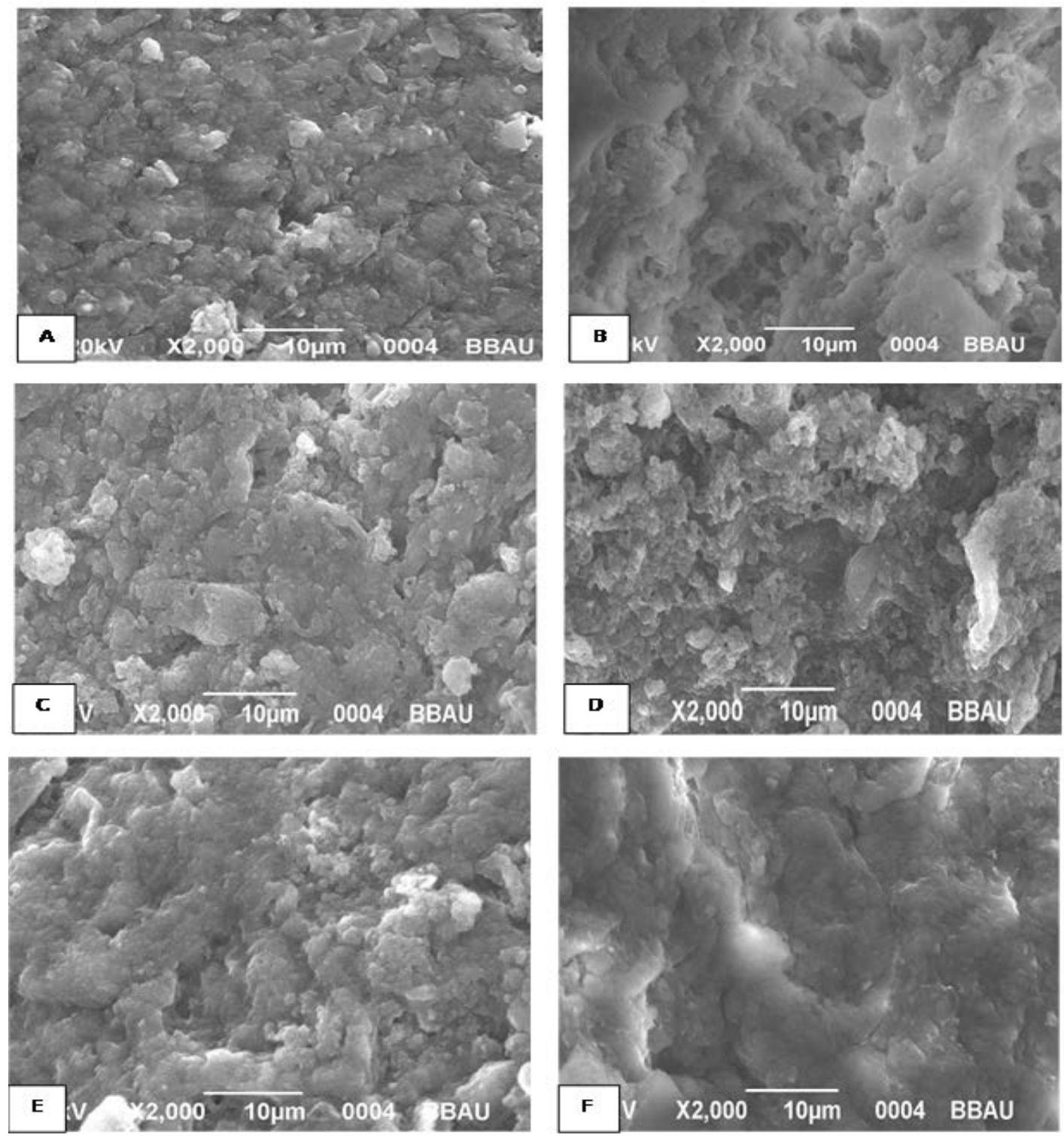

Fig. 3: SEM evaluation of esophagitis tissue after oral treatment (A) Control, (B) esophagitis conrol (C) pantoprazole (30 mg/kg), (D) naringin (100 mg/kg), (E) naringin (200 mg/kg) and (F) naringin $(300 \mathrm{mg} / \mathrm{kg})$

inflamed tissue was performed. SOD is a free radical scavenging enzyme, which neutralizes superoxide free radical in normal physiological situations ${ }^{[23]}$. Again, SOD levels were also decreased among the esophagitis control groups but this enzyme level restored to normal in naringin treated groups. Therefore, it might be concluded that naringin was active against esophagitis treatment via inhibiting the release of reactive oxygen species. Later, microscopic observation and SEM were performed to check the lesion at esophagus portions of both esophagitis control and naringin treated groups. Lesions and ulcers were observed in un-treated esophagitis control, while these were found to be absent in the naringin-treated groups.

Results of this investigation suggested that naringin could be effective in esophagitis by the mechanism of action of inhibition of reactive oxygen species and free radicals. Naringin's phenolic hydroxyl group, could be involved in scavenging free radicals ${ }^{[10]}$. Therefore, naringin might prove to be a better alternative drug for esophagitis treatment in future.

\section{Acknowledgement:}

Dr. Sudipta Saha wishes to express his thanks to the University Grants Commission (UGC), New Delhi, India, for providing UGC-MRP Grant (Project No. 42680/2013(SR)).

\section{Conflicts of interest:}

The author declares that they have no conflict of interest. 


\section{Financial support and sponsorship:}

Nil.

\section{REFERENCES}

1. Dent J, El-Serag HB, Wallander MA, Johansson S. Epidemiology of gastro-esophagitis reflux disease: a systematic review. Gut 2005;54:710-7.

2. Souza RF, Huo X, Mittal V, Schuler CM, Carmack SW, Zhang $\mathrm{HY}$, et al. Gastroesophagitis reflux might cause esophagitis through a cytokine-mediated mechanism rather than caustic acid injury. Gastroenterology 2009;137:1776-84.

3. Kin DS, Tertychnyy A, De-hertogh G, Geboes K, Tack J. Intestinal immune activation in presumed post-infectious functional dyspepsia. Neurogastroenterol Motil 2009;21:83256.

4. Mitushing S, Jang JS, Yoshizawa Y, Osawa S, Sugimoto K, Sato Y, et al. Proton pump inhibitor therapy before and after endoscopic submucosal dissection: a review. Diagn Ther Endosc 2012;2012:791873.

5. Goel RK, Sairam K. Antiulcer drugs from indigenous sources with emphasis on Musa sapientum, Tamrabhasna, Asparagus racemosus and Zingiber officinale. Indian J Pharmacol 2002;34:100-10.

6. Nijveldt RJ, van Nood E, van Hoorn DE, Boelens PG, van Norren K, van Leeuwen PA. Flavonoids: a review of probable mechanisms of action and potential applications. Am J Clin Nutr 2001;74:4180-25.

7. Bharti S, Rani N, Krishnamurthy B, Arya DS. Preclinical Evidence for the Pharmacological Actions of Naringin: A Review. Planta Med 2014;80:437-51.

8. Cavia-Saiz M, Busto MD, Pilar-Izquierdo MC, Ortega N, Perez-Mateos M, Muñiz P. Antioxidant properties, radical scavenging activity and biomolecule protection capacity of flavonoid naringenin and its glycoside naringin: a comparative study. J Sci Food Agri 2010;90:1238-44.

9. Rezk BM, Haenen GR, van der Vijgh WJ, Bast A. The antioxidant activity of phloretin: the disclosure of a new antioxidant pharmacophore in flavonoids. Biochem Biophys Res Commun 2002;295:9-13.

10. Takasawa R, Takahashi S, Saeki K, Sunaga S, Yoshimori A, Tanuma S. Structure activity relationship of human GLO
I inhibitory natural flavonoids and their growth inhibitory effects. Bioorg Med Chem 2008;16:3969-75.

11. Heijnen CG, Haenen GR, van Acker FA, van der Vijgh WJ, Bast A. Flavonoids as peroxynitrite scavengers: the role of the hydroxyl groups. Toxicol In Vitro 2001;15:3-6.

12. Martín MJ, Marhuenda E, Pérez-Guerrero C, Franco JM. Antiulcer effect of naringin on gastric lesions induced by ethanol in rats. Pharmacol 1994;49:144-50.

13. Kushwaha PS, Raj V, Singh AK, Keshari AK, Saraf SA, Mandal SC. Antidiabetic effects of isolated sterols from Ficus racemosa leaves. RSC Adv 2015;5:35230-37.

14. Rao CV, Kumar VM. Effect of quercetin, flavonoid and alphatocopherol, an antioxidant vitamin on experimental reflux oesophagitis in rats. Eur J Pharmacol 2008;589:233-8.

15. Pratyusha S, Elumalai PJA. Study on phytochemical profile and antiulcerogenic effect of Malachra capitata (L.) in Albino Wistar rats. Int J Preclin Pharm Res 2012;3:97-103.

16. Prasad KNB, Ramesh A, Naresh P, Vinay Kumar I, Naresh D. Evaluation of antiulcer and in vitro antioxidant activity of methanolic extract of Psidium guajava root in albino Wistar rats. Int J Phytopharmacol 2014;5:59-67.

17. Gupta SK, Gautam S, Rawat JK, Singh M, Saraf SA, Kaithwas G. Efficacy of variable dosage of aspirin in combating methotrexate-induced intestinal toxicity. RSC Adv 2015;5:9354-60.

18. Ong MM, Latchoumycandane C, Boelsterli UA. Troglitazoneinduced hepatic necrosis in an animal model of silent genetic mitochondrial abnormalities. Toxicol Sci 2007;97:205-13.

19. Shin YK, Sohn UD, Choi MS, Kum C, Sim SS, Lee MY. Effects of rutin and harmaline on rat reflux oesophagitis. Auton Autacoid Pharmacol 200;22:47-55.

20. Giri AK, Rawat JK, Singh M, Gautam S, Kaithwas G. Effect of lycopene against gastroesophagitis reflux disease in experimental animals. BMC Complement Altern Med 2015;15:1-7.

21. http://scholarbank.nus.sg/bitstream/handle/10635/22140/ SUDIPTA\%20SAHA.PDF?sequence $=1$.

22. Karaman A, Iraz M, Kirimlioglun H, Karadag N, Tas E, Fadillioglu E. Hepatic damage in biliary obstructed rats is ameliorated by leflunomide treatment. Pediatr Surg Int 2006;22:701-08.

23. Pietta PG. Flavonoids as antioxidants. J Nat Prod 2000;63:1035-42. 